\title{
Breakdown and Pitting Formation of Anodic Film Aluminum Alloy (3003)
}

\author{
Dr. Sami A. Ajeel (Corresponding author) \\ Dept.of Production and Metallurgy Eng., Univ. of Technology Iraq -Baghdad \\ 52-Street -Al-Sana'a Street, Baghdad, Iraq \\ Tel: 96-4-790-154-0922Ｅ-mail: samiabualnon@yahoo.com \\ Dr.Nahidh W. Kasser \\ Chemical Engineering Dept., Univ. of Technology. Iraq -Baghdad \\ 52-Street -Al-Sana'a Street, Baghdad, Iraq \\ Tel: 96-4 -790-547-5566 E-mail: dr_nahidh@yahoo.com \\ M.Sc. Basheer A. Abdul-Hussein \\ Chemical Engineering Dept., Univ. of Technology. Iraq-Baghdad \\ Al-Yarmook-616, Baghdad, Iraq \\ Tel: 96-4 -790-136-1896Ｅ-mail: basheer2004@gmail.com
}

\begin{abstract}
Aluminum alloy (3003) has been anodized using sulfuric acid solution. To study the characteristic of the anodic film of aluminum alloy (3003); four variables are examined in term of anodic film thickness, these are current density ranging between $1.5-3.5 \mathrm{~A} / \mathrm{dm}^{2}$, electrolyte concentration ranging between $10-20$ Vol.\%, electrolyte temperature between $10-30^{\circ} \mathrm{C}$ and anodizing time between $10-50 \mathrm{~min}$.

The study shows that the time of anodizing and current density has positive dependence of great significance on the anodic film thickness of aluminum alloy (3003) while the other two studied variables (i.e. concentration and temperature of electrolyte) show little dependence on the film thickness.

When conditional Hookes and Jeeves optimization method is used, optimum conditions of aluminum alloy (3003) in terms of maximum thickness are found equal to:

Current density $\left(\mathrm{A} / \mathrm{dm}^{2}\right) 3.5$

Acid concentration (Vol. \%) 10

Electrolyte temperature $\left({ }^{\circ} \mathrm{C}\right) 19$

Time of anodizing (min.) 50

Aluminum alloy (3003) specimens at optimum conditions are anodized and comparison studies between anodized and un-anodized specimens are carried out in terms of:

1) the roughness and hardness of anodic film.

2) the corrosion rates in $3.5 \% \mathrm{NaCl}$ solution by:

a) immersion test.

b) polarization curves.

3) examining microstructure before and after anodizing of both types and their corrosion specimens by optical microscope and X-ray diffraction.

In general, it is found that the surface roughness and hardness values for the anodized specimens are greater than that of un-anodized specimens because of the very much thicker oxide coating compare with the natural oxide (atmospheric oxide) whose improved physical and chemical properties. Also, the corrosion rates for anodized specimens are lower than that for un-anodized ones.

The polarization behavior for anodizing alloy shows that the breakdown potentials are shifted to more noble direction than bare metals due to anodizing.
\end{abstract}


The study also shows that the Breakdown of passive film and pitting formation occurred at $(-661 \mathrm{mV})$ for un-anodized alloy, while $(-410 \mathrm{~V})$ for anodized alloy. The observed pits are clearly not deep and small in size in large numbers compared with the unanodized specimens.

Keywords: Aluminum, Anodizing, Polarization, Pitting formation

\section{Fundamentals of Anodizing}

Aluminum has a very high chemical affinity with oxygen. Therefore, a very thin oxide film of a few angstroms can be formed easily on exposed aluminum surface to air. This oxide film is called "air-formed oxide film" or "natural oxide film." The thickness of this film is very small, therefore, it can't be used as a protective film for preventing corrosion(Anodizers plaza. 1997).

Anodizing is a process in which the surface of a metal, commonly aluminum, is oxidized to form a porous and durable surface coating(East West dye Company, 2004). The aluminum part, which becomes the anode, is submerged in a solution, commonly sulfuric acid, while a current is applied. This is the opposite of elector plating where the parts become the cathode (negatively charged) and positively charged metal ions in solution are deposited on to the metal surface to form a coating. During the anodizing process, the surface aluminum becomes oxidized (loss of electrons) and carries a positive charge. The aluminum quickly reacts with water to form aluminum oxide $\mathrm{AL}_{2} \mathrm{O}_{3}$ and hydrogen gas(Corrosion Doctors Web, 2003)( SAF company, 2003).

The reactions in the anodizing process are explained as follows:-

The anode reaction; there is an oxidation process taking place on the anode surface (equation 1)

$2 \mathrm{Al}$ (metal) $+3 \mathrm{H}_{2} \mathrm{O} \longrightarrow \mathrm{Al}_{2} \mathrm{O}_{3}$ (oxide coating) $+6 \mathrm{H}^{+}+6 \mathrm{e}^{-} \ldots .$.

The cathodic reaction; there is reduction process taking place on the cathode surface. Hydrogen gas is evolved at the cathode and appears as bubbles during the anodizing process, (equation (2))

$6 \mathrm{H}^{+}+6 \mathrm{e} \longrightarrow 3 \mathrm{H}_{2} \quad$ (gas)

The structure of the porous type of anodic oxide coating is shown in figure (1), and can be seen to comprise hexagonal columns each with a central pore. This pore reaches down to a thin compact barrier layer, which is continuously formed and transformed into the porous form during the process(V.F.Henley, 1982)(G.S.Frankel, 2004).

\section{Experimental Design and Work}

2.1 Box- Wilson Design

The Box-Wilson experimental design is a general series of experiments that have been developed for second order response surface(D.C. Montgomery, 1976).

The general form of a quadratic (second order model) polynomial is illustrated by following equation:

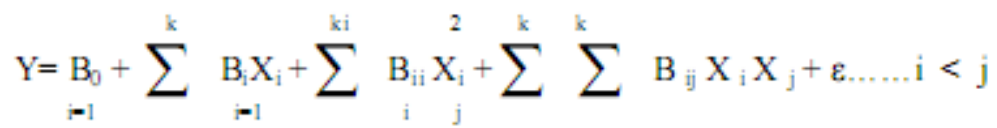

where $\varepsilon$ is a random error component and $\mathrm{Y}$ is the objective function and ki is the number of variables in the system.

For four variables, the quadratic polynomial equation can be represented as follows:

$$
\begin{array}{rl}
2 & 2 \\
\mathrm{Y}= & \mathrm{B}_{0}+\mathrm{B}_{1} \mathrm{X}_{1}+\mathrm{B}_{2} \mathrm{X}_{2}+\mathrm{B}_{3} \mathrm{X}_{3}+\mathrm{B}_{4} \mathrm{X}_{4}+\mathrm{B}_{11} \mathrm{X}_{1}+\mathrm{B}_{22} \mathrm{X}_{2}+\mathrm{B}_{33} \mathrm{X}_{3}+\mathrm{B}_{44} \mathrm{X}_{4} \\
& +\mathrm{B}_{12} \mathrm{X}_{1} \mathrm{X}_{2}+\mathrm{B}_{13} \mathrm{X}_{1} \mathrm{X}_{3}+\mathrm{B}_{14} \mathrm{X}_{1} \mathrm{X}_{4}+\mathrm{B}_{23} \mathrm{X}_{2} \mathrm{X}_{3}+\mathrm{B}_{24} \mathrm{X}_{2} \mathrm{X}_{4}+\mathrm{B}_{23} \mathrm{X}_{2} \mathrm{X}_{3}
\end{array}
$$

The total number of experiments $(\mathrm{N})$ needed according to the central composite rotatable design is estimated according to the following equation:

$\mathrm{N}=2^{\mathrm{k}}+2 \mathrm{k}+1$

where: $2^{\mathrm{k}}$ : is the fractional point, $2 \mathrm{k}$ : is the axial point, 1 : is the center point; plus 3 additional experiments to take the lack of fit and experimental error into account(C.F.Jeffwn, Michael Hamada, 2000).

The coded variables take the value between -2 and 2 in accordance with the central composite rotatable suggested by Cochrun(C.F.Jeffwn, Michael Hamada. 2000). The range of real variables for the system could be 
represented in table (1). Table (2) shows the relationship between the coded level and corresponding real variables

\subsection{Experimental Work}

The present study includes the achievement of experiment work through central composite rotatable designed method to create specimens of different artificial film thickness using sulfuric acid anodizing process.

The procedures of anodizing are carried out under (Defence standard 03-25Issue 4-2003)(Gazapo, S., Jose,l., Gonzalez,F. 1986) \& Military specification (MIL-A-8625 F-1993)(Military Specification. 1993).

The specimens used for this study were aluminum alloy (3003) (Source: Aluminum Co. TH. 0.7 (Italian made)) cut into the dimension $(1 * 3 * 0.07)$.

These specimens were examined at different variables (current density, acid concentration, time and temperature) and the results were analyzed by using (Statistica software) and (Hook and Jeeves method) to obtain the optimum operation conditions.

Analysis of these specimens was carried out using (spark technique) in AL-NASER Company. Table (3) shows the result of the analysis of shows the aluminum alloy (3003)

Stainless steel sheet type 304 with dimensions of $(7 * 3 * 0.07) \mathrm{Cm}$ was used as cathode

\subsection{Anodizing steps}

1) Oil, grease, and general dirt were properly removed with acetone at $25^{\circ} \mathrm{C}$

2) Alkaline etching: $5 \mathrm{wt} \%$ sodium hydroxide solution was used with an operating temperature of $40-50{ }^{\circ} \mathrm{C}$. The specimen was placed in the etching solution for a period of 5 minutes

3) Acid etching the specimens were treated in $5 \% \mathrm{HNO}_{3}$ solution for about 5 minutes at $25^{\circ} \mathrm{C}$ to remove the black layer (desmuting) that was formed on the surface.

4) Electropolishing

The specimen was polished by using the electro polishing technique by immersion in the solution consists of:

Phosphoric acid $\quad 75 \%$

Sulfuric acid $\quad 25 \%$

Nitric acid $\quad 0.1 \% \quad$ (this $\%$ as in ref. 5 )

The time for immersion is $10 \mathrm{~min}$. and the temperature of electrolyte is $90{ }^{\circ} \mathrm{C}$ and the current density is 15 $\mathrm{Amp} / \mathrm{dm}^{2}$.

The aluminum strip was connected to the positive terminal where it becomes (anode) while the stainless steel strip was connected to the negative terminal to be (cathode). Figure (2) shows schematic diagram for the whole assembly of the anodizing apparatus respectively.

The operating conditions were adjusted to meet predetermined conditions that were already designed according to Box-Welson technique.

The compressed air was pumped at a constant rate, water bath temperature was adjusted to the required value.

The specimen was rinsed with running water followed by distilled water to remove the excess solution on it and then dried in a drying furnace at $50{ }^{\circ} \mathrm{C}$ for 30 minutes and stayed in dissector about $30 \mathrm{~min}$

When the anodizing process (sulfuric acid process) stage was completed according to the predesigned condition, the specimen was dipped in a flask filled with hot distilled water and kept for 20 minutes at $97-99{ }^{\circ} \mathrm{C}$ in order to seal the porous anodic film, then the specimens were dried in a drying furnace at $50{ }^{\circ} \mathrm{C}$ for 30 minutes and stayed in dissector about $30 \mathrm{~min}$. and weighted $\left(\mathrm{W}_{2}\right)$.

Anodic film was stripped using the following solution:

Phosphoric acid (s.g. 1.75) $\quad 35 \mathrm{ml}$

Chromic acid $20 \mathrm{~g}$

Distilled water to 1 liter

The time for immersion is $10 \mathrm{~min}$. and the temperature of electrolyte is $100^{\circ} \mathrm{C}$ 
After stripping process, the specimens were rinsed with running water followed by distilled water to remove the excess solutions. Then dried in a drying furnace at $50{ }^{\circ} \mathrm{C}$ for 30 minutes and stayed in dissector about 30 minutes and weighted $\left(\mathrm{W}_{3}\right)$ (Military Specification. 1993)(Ling Hao ph. D. 2001).

\subsection{Tests For Anodic Film}

\section{1) Continuity Tests}

\section{2) Electrical Test}

A simple electrical circuit was designed to inspect the surface coating of (3003) aluminum alloy and check if there is any damage or crack in the anodic surface. The equipment is as illustrated in figure (3).

The resistor is adjusted so that brush contact and the probe are directly connected current of 1 A passes. With the pointed probe making effective contact on to the aluminum, if there are any crack or disconnect in the surface layer the circuit is closed and the current is passed.

\section{3) Chemical Test}

Chemical test was carried out to make sure that the entire surface was coated without any damage; the solution used for this test consisted of:

$\begin{array}{lc}\text { Copper sulfate } & 20 \mathrm{ml} \\ \text { Hydrochloric acid } & 20 \mathrm{ml} \\ \text { Water } & 1 \text { liter }\end{array}$

The time for immersion was $5 \mathrm{~min}$ at $15-20 \mathrm{C}^{\circ}$. The reagent does not affect an anodic film, however black spots appear where no anodic film is present. This method will also detect cracks in the coating caused by overheating or bending(V.F.Henley. 1982).

\section{4) Coating Thickness Test}

The coating thickness were calculated by using (Gravimetric determination of coating weight and thickness) according to the standard test method (ASTM B 680-80)(G.S.Frankel. 2004), from the weight loss measured in equation (5). The specimens were weighed before immersion in the following solution:

$\begin{array}{ll}\text { Phosphoric acid } & 35 \mathrm{ml} \\ \text { Chromic acid } & 20 \mathrm{~g}\end{array}$

Deionized water $1 \mathrm{~L}$

The time for immersion is $10 \mathrm{~min}$. and the temperature of electrolyte is $100^{\circ} \mathrm{C}$

This solution does not attack aluminum but dissolves the thin oxide film and leaving the surface of aluminum.

The specimen is weighed before and after coating removal. The loss in weight divided by the area provides a figure for the mass of coating per unit area (P.Marcus and J.M.Herblin, 1995).

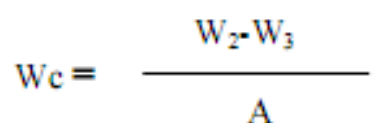

Where:

$\mathrm{W}_{2}=$ weight of a sample with anodic coating in (g.); $\mathrm{W}_{3}=$ weight of a sample after stripping in (g.);

$\mathrm{A}=$ surface area $\left(\mathrm{dm}^{2}\right)$.

From the weight loss measured above, the coating thickness can be calculated from the equation $(6)^{(2,16)}$ :

$$
\mathrm{Y}=\frac{\left(\mathrm{W}_{2} \cdot \mathrm{W}_{3}\right) \times 10^{4}}{\mathrm{~A} \times \rho}
$$

where: $\mathrm{Y}=$ coating thickness in micron

\section{5) Roughness Test}

Measuring the surface roughness of the anodized aluminum film was carried out using (Talysurf-Taylor-Hobson Company-England) following specifications (Ling Hao, 2001): 
Stylus material: $\quad$ Diamond

Stylus force: $\quad 100 \mathrm{mg} . \mathrm{f}$

The arithmetic average values $(\mathrm{Ra})$ for anodized specimens were calculated directly from the instrument. The examinations were carried out for bare and anodized aluminum and 3003-Al- alloy specimens.

\section{6) Hardness Test}

Vickers microhardness test was carried out for the specimens under optimum conditions for (3003) alloy (before and after anodizing) by using LIETZ Optical Microscope (W.Germany). The magnification was X100 and the applied load was $100 \mathrm{~g}$. The average of 5 readings of the indentation length was taken while; the applied load was kept for $20 \mathrm{sec}$ for each reading .The Vicker microhardness (HV) was calculated according to the following equation:

\section{$1.854 \mathrm{~F}$ \\ $\mathrm{HV}=$ \\ $\mathrm{D}^{2}$}

\subsection{Corrosion Rate Measurement}

The corrosion rate measurements were done in two types:

1) Weight Loss Measurements Technique

The corrosion rates for aluminum and its alloys are low in all electrolytes in the intermediate $\mathrm{pH}$ range between 4 to 8.5 where $\mathrm{Al}_{2} \mathrm{O}_{3}$ provides a protective film. At higher and lower $\mathrm{pH}$ value, where the oxide is soluble, the corrosion rate may be high depending on other ions present(Broli, A. and Holtan, H. 1973), (this method according to the ASTM -G31-72) (Burger, F.J. and Cheseldine, D.M., 1962).

Mars G.F and Nobert began promoting the formula for calculating corrosion rate in mils per year in 1945(Mars G.F. and Norbert D.G, 1978), and it is now widely used. This formula is(Corrosion Doctors Web. 2003)( Richardson J.A.and Wood G.C. 1970) :

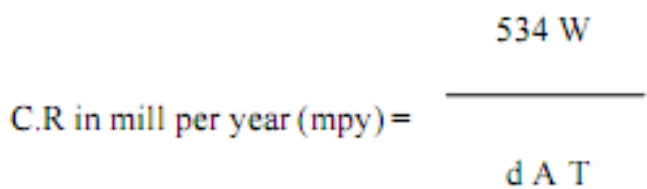

where: W: The weight loss in mg., d: The density of specimen in $\mathrm{g} . / \mathrm{Cm}^{3}$.

A: The surface area of the specimen in in $^{2}$. T: The time of exposure in $\mathrm{hr}$.

Specimens of $(1 * 3 * 0.7 \mathrm{Cm})$ for $(3003)$ aluminum alloy were used with a small hole of $1 \mathrm{~mm}$ diameter. Samples were abraded in sequence under running tap water by using 220,320,400,600 and 1000 grades of emery paper and then, washed with running tap water followed by distilled water, dried with a clean tissue and then kept in a desiccator over silica gel bed until the time to use. Other specimens were prepared by anodizing (aluminum alloy 3003 ) in sulfuric acid. The dimensions of each sample were carefully measured with a digital vernier to the $2^{\text {nd }}$ decimals of millimeter and weighed to the $4^{\text {th }}$ decimal of gram.

For the weight loss measurements, the metal specimens were completely immersed in $125 \mathrm{Cm}^{3}$ of $3.5 \% \mathrm{NaCl}$ solution at $25^{\circ} \mathrm{C}$ in test tubes for $(3,6,9,12,15,20,25,30)$ days and then recorded the differences in weight.

\section{2) Electrochemical Corrosion Cell}

The polarization was carried out in a 1-letter beaker consisting of working, counter and reference electrodes as shown in figure (4).

The working electrode was $(1 * 1) \mathrm{Cm}$ of (3003) aluminum alloy (other side and thickness of the specimens were coated with the epoxy to prevent exposure to the solution), held by aluminum jigs designed to hold the specimens, it was covered with shrinkage tube to provide the bad contact and hold it stable in the cell.

The counter electrode was a platinum type (Tacussel Pt-F05/30) seated directly opposite to the working electrode.

The reference electrode was a standard calomel electrode (SCE) type (Tacussel type C4) bridged by a Laggin-Haber probe. The distance between the electrode surface and the Laggin-Haber capillary was set at about the optimum value of $1 \mathrm{~mm}$ to minimize the experimental error due to IR drop. 
A thermometer was used to maintain the solution temperature within $\pm 1^{\circ} \mathrm{C}$.

After the supplying of $(3.5 \%) \mathrm{NaCl}$ solution to the cell, the free corrosion potential was measured with respect to $(\mathrm{SCE})$ with time using the digital multimeter. $\mathrm{E}_{\text {corr }}$ value was automatically record with variable value, till it reaches a steady state value. This steady state value can be considered the actual $\mathrm{E}_{\text {corr }}$ in this environment.

Polarization was carried out by using potentiostat (type PRT 10-0.5). The potentiostatic was connected to voltmeter and ammeter to read the applied voltage and current density respectively.

The constant potential was applied by the potentiostatic while the change in current was read and recorded from the high resistance multimeter.

The applied potentials were used for cathodic and anodic polarization for bare aluminum alloy (3003) and anodized .The potentials range were determined with the help of corrosion potential obtained in open circuit test.

\section{3) Microstructure Examination}

The microstructure evolution was investigated by means of optical microscope using microscope (Nikon-120, Japan) connected to the computer at the Ministry of Science and Technology -Baghdad. The specimens were prepared from $3003 \mathrm{Al}$ alloy with $(1 * 1) \mathrm{Cm}$ before and after anodizing and also after polarization in $3.5 \% \mathrm{NaCl}$ solution to note the breakdown in the passive film and pitting formation.

\section{Results and Discussion}

\subsection{Postulating The Mathematical Model}

A second order polynomial would correlate the four variables (i.e. current density, electrolyte concentration, electrolyte temperature and time of anodizing) with the thickness of the oxide film of the specimens

Table (5) shows the experimental measured thickness values of the oxide film of the conducted specimens and the estimated one through implementing the second order polynomial model.

Therefore, the final form of the proposed model was as follows:

$$
\begin{aligned}
\mathrm{Y}=24.048+ & 4.388 \mathrm{X}_{1} \cdot 0.669 \mathrm{X}_{2} \cdot 1.579 \mathrm{X}_{3}+7.088 \mathrm{X}_{4}+0.0098 \mathrm{X}_{1}+0.090 \mathrm{X}_{2} \cdot 1.567 \mathrm{X}_{3}+0.139 \mathrm{X}_{4}^{2}+ \\
& 1.076 \mathrm{X}_{1} \mathrm{X}_{2}+0.668 \mathrm{X}_{1} \mathrm{X}_{3}-0.0575 \mathrm{X}_{1} \mathrm{X}_{4}-0.0663 \mathrm{X}_{2} \mathrm{X}_{3}-1.458 \mathrm{X}_{2} \mathrm{X}_{4}-0.226 \mathrm{X}_{3} \mathrm{X}_{4} \ldots .(9)
\end{aligned}
$$

Equation (9) is applied to estimate the thickness of the oxide film as listed in column (y) Table (5).

\subsection{Analysis for Significant Values}

From the equation (9) it is possible to compute estimated (Y) and the corresponding residuals (from statistica software)):

$\mathrm{e}_{\mathrm{i}}=(\mathrm{Y}-\mathrm{y})$

An estimation of the experimental error variance $\left(\mathrm{S}_{\mathrm{r}}{ }^{2}\right)$ is obtained by dividing the residual sum of squares $\left(\mathrm{e}_{\mathrm{i}}\right)$ by number of degree of freedom $(\gamma)$; where:

$$
\gamma=\mathrm{N}_{\mathrm{i}}-\mathrm{N}_{\text {coff }}
$$

where: Ni: No. of experiment, $\mathrm{N}_{\text {coff }}$ No. of coefficient in the model

$\gamma=28-15=13$

$$
\mathrm{S}_{\mathrm{r}}^{2}=\Sigma \mathrm{e}_{\mathrm{i}}^{2} / \gamma
$$

The estimated variances of coefficients (Sb2) are then calculated by the following formula:

$\mathrm{S}_{\mathrm{b}}^{2}=\mathrm{S}_{\mathrm{r}}^{2} / \Sigma \mathrm{X}^{2}$

The significant coefficient can be estimated by comparing the value of $\left(\mathrm{B}^{2} / \mathrm{S}_{\mathrm{b}}{ }^{2}\right)$ to the critical value $\mathrm{F}_{0.95}$ $(1,13)=4.67$ of the $\mathrm{F}$-distribution at $95 \%$ level of confidence ${ }^{(73)}$. The results of these calculations are shown in table (6) for aluminum alloy (3003).

The new response function is then written in the following form:

2

$$
\mathrm{Y}=24.048+4.388 \mathrm{X}_{1} \cdot 1.579 \mathrm{X}_{3}+7.088 \mathrm{X}_{4} \cdot 1.567 \mathrm{X}_{3} \cdot 1.458 \mathrm{X}_{2} \mathrm{X}_{4} \ldots
$$




\subsection{Estimating the Optimum Conditions}

According to Equation (9), using Hook and Jeeves pattern conditional method in terms of maximum thickness of the anodic film, the optimum conditions were obtained. The optimum conditions of the studied variables in coded and real form are listed in table (7) below for aluminum alloy (3003)

The statistical analysis of the response function, Equation (9), is shown the dependence of the thickness of the oxide film on current density $\left(\mathrm{X}_{1}\right)$, electrolyte concentration $\left(\mathrm{X}_{2}\right)$, temperature $\left(\mathrm{X}_{3}\right)$, and time of anodizing $\left(\mathrm{X}_{4}\right)$ in the following sequence:

$$
\mathrm{X}_{4}>\mathrm{X}_{1}>\mathrm{X}_{3}>\mathrm{X}_{2}
$$

It shows that the current density $\left(\mathrm{X}_{1}\right)$ and time of anodizing $\left(\mathrm{X}_{4}\right)$ show a significant dependence on the film growth in comparison with the other two variables, i.e. electrolyte concentration $\left(\mathrm{X}_{2}\right)$ and temperature $\left(\mathrm{X}_{3}\right)$. The latter variables show the lowest dependence that might regarded.

Figure (6-a) indicate the dependence of current density on film thickness of aluminum alloy (3003). In this Figure the thickness of aluminum oxide is directly proportional to the current density. Normally, the thickness of the oxide film increases to a maximum value at which current encourages the reaction of the oxygen with aluminum, i.e. to produce aluminum oxide.

Figure (6-d) illustrate the effect of concentration on film thickness of aluminum alloy (3003). It shows no distinct change in film thickness for whilst a drop in film thickness for aluminum alloy (3003) is noticed. The lowest thickness value is at a concentration of $20 \mathrm{Vol} . \%$, which contributes to the great tendency of film dissolution in higher concentration of sulfuric acid.

\section{1) Roughness Test}

The arithmetic average values of the roughness are listed in Table (7)

The roughness of anodized surface is greater than that of untreated one because during anodizing a new phase is formed, i.e. $\mathrm{Al}_{2} \mathrm{O}_{3}$. The weight and dimensions of this phase are different from that of base metal that is already replaced by the anodic film.

2) Hardness Test

The Vickers micro-hardness testing results are listed in Table (8).

From above results, it is obvious that the hardness of aluminum alloy (3003) is higher than pure aluminum due to the presence of $\mathrm{Mn}$ impurities in the composition of the alloy, these impurities increase the mechanical properties of the alloy but reduce the corrosion resistance as shown later.

\subsection{Corrosion Rate Measurements}

a) Immersion Test

Anodized film reduces the corrosion rates aluminum alloy (3003) due to the passive layer added on the surface, $\mathrm{Al}_{2} \mathrm{O}_{3}$. This layer coats the surface and prevents the aggressive solution attacking the metal surface as compared with the bare specimens.

\section{b) Potentiostatic Polarization Measurement}

The potentiostatic polarization behavior of aluminum alloy (3003) (before and after anodizing) in $3.5 \% \mathrm{NaCl}$ solution is presented in Figure (9).

Figure (9) shows the effect of anodizing in $3.5 \% \mathrm{NaCl}$ solution at $25^{\circ} \mathrm{C}$, on the relationship between current density and potential of aluminum alloy (3003). In these figures it seems that:

1) $E_{\text {corr }}$ for anodized Al-alloy (3003) shift to more noble direction compared with bare specimens due to sharp anodic kinetic change because of anodized film formation.

2) the cathodic branch of the polarization curve shows over a wide potential range that in the case of anodized specimens, the coating surface is more catalytic to the $\mathrm{H}_{2}$ evolution reaction than the unprotected surface, i.e., the anodized coating has an electronic resistivity of order:

$$
\mathrm{H}_{2} \mathrm{SO}_{4} \text { anodized }>\text { Unprotected one }
$$

3) Suppressing the kinetic of anodic polarization curves at anodic sites on the surface is more pronounced Al-alloy (3003), the anodic current density for anodized specimens reduced high value than unprotected specimens. 
4) Breakdown potential of anodized specimen shifts to more noble direction due to the presentation oxide film on the surface.

Figure (10) shows the pitting formation for anodized surface for aluminum alloy (3003). The observed pits are clearly not deep and small in size in large numbers compared with the unanodized specimens

Corrosion rate is calculated by using the equation (14)(Denny A.Jones. 1996)(Uhlig, H.H., and Revie, R.W. 2006).

$$
0.13 \mathrm{I}_{\text {carr }} \times \mathrm{E} . \mathrm{W}
$$

\section{$\mathrm{CR}(\mathrm{mpy})=$}

Where:

\section{A $x \mathrm{~d}$}

$\mathrm{I}_{\text {corr }}$ : corrosion current, $\mu \mathrm{A}, \mathrm{E} . \mathrm{W} .:$ Equivalent weight of the specimen in g. / equivalent.

d: Density of specimen in $\mathrm{g} . / \mathrm{cm}^{3}$, A: Surface aria in $\mathrm{Cm}^{2}$.

\section{Conclusions}

The following conclusions can be drawn from this study:

1) The second order polynomial regression analysis of the objective function (thickness) in terms of four variables (i.e., current density, concentration of electrolyte, temperature and time of anodizing) gives equation (9), which adequately describe the behavior of the process throughout the studied range.

2) The above variables affect the film thickness in following order:

Time of anodizing $>$ Current density.

3) The corrosion potential for anodizing specimens are shifted more positive than unanodizing specimens

4) The corrosion rates for unprotected specimens are found to be higher than anodized specimens.

5) Pitting potential for aluminum alloy (3003) is higher than unprotected materials.

The roughness and Hardness for anodizing specimens are found to be higher than un-anodized specimens

\section{References}

Anodizers plaza. (1997). "Theories of Anodized Aluminum - 100 Q. and A.”On-line lecture, Scince and technology of Aluminum surface treatment, Japan, 1997.

Broli, A. and Holtan, H., Corros.Sin. (1973). Vol.13, p-237.

Burger, F.J. and Cheseldine, D.M. (1962). J.electroch.Soc, Vol.107, p-1025, 1962

C.F.Jeffwn, Michael Hamada. (2000). "Experimets; Planning, Analysis", John-Wiley and sons New York, 2000.

C.F.Jeffwn, Michael Hamada. (2000). "Experimets; Planning, Analysis", John-Wiley and sons New York, 2000

Corrosion Doctors Web. (2003). "Inorganic Coating-Anodizing".

Corrosion Doctors Web. (2003). "Inorganic Coating -Anodizing". www.corrosion-doctors.org/metal coating/inorganing.html.

D.C. Montgomery. (1976). "Design and analysis of Experiments", John-Wiley and sons New York, 1976.

Denny A.Jones. (1996). "Principles and prevention of corrosion", USA, prentice Hall, 1996, $2^{\text {nd }}$ edition.

East West dye Company. (2004). "technical info.- Aluminum Anodizing",2004

G.S.Frankel. (2004). "Localized Corrosion of Metals; A review of the Rate-Controlling Factors in Initiation and Growth", Fontana Corrosion Center, 2004.

G.S.Frankel. (2004). "Localized Corrosion of Metals; A review of the Rate-Controlling Factors in Initiation and Growth”, Fontana Corrosion Center, 2004.

Gazapo, S., Jose,l., Gonzalez,F. (1986). "Prosess for the electrolytic coloring of aluminum or aluminum alloys",US patent 4,632,735,1986

Ling Hao ph. D. (2001). "Sealing Enhance Anodic Coating Performance", Metalast technical report, 2001.

Mars G.F. and Norbert D.G. (1978). "Corrosion Engineering McGraw- Hill, Inc. $2^{\text {nd }}$ ed, 1978. 
Military Specification. (1993). Mil-A-8625F, Military specification,"Anodic coating for aluminum and Aluminum Alloys", The department of defence, 1993

P.Marcus and J.M.Herblin," Corros.Sci."341123,1993.

Richardson J.A.and Wood G.C. (1970). Corros.Sci., Vol.10,p-313,1970.

SAF company. (2003). "painting vs Anodizing”, 2003. www.saf.com/painting vs anodizing in architecture.html. Uhlig, H.H., and Revie, R.W. (2006). "Corrosion and Corrosion Control", John Wiley and sons, 2006.

V.F.Henley. (1982). "Anodic oxidation of aluminum and its alloy",UK,Pergamon Press.

W.Canning. (2001). "Canning Hand Book on electroplating"published by canning co. ltd.twenty, first edition, 2001 .

Table 1. The experimental range of variables

\begin{tabular}{|c|c|c|c|}
\hline Current density (Amp / $\left.\mathbf{d m}^{\mathbf{2}}\right)$ & Concentration ( Vol ) \% & Temperature (C) & Time (min.) \\
\hline $3.5-1.5$ & $20-10$ & $30-10$ & $50-10$ \\
\hline
\end{tabular}

Table 2. The relationship between coded code level and corresponding real variable

\begin{tabular}{|c|c|c|c|c|c|}
\hline Variables & \multicolumn{5}{|c|}{ levels } \\
\hline$X_{1}, X_{2}, X_{3}, X_{4}$ & -2 & -1 & $\mathbf{0}$ & 1 & 2 \\
\hline $\mathrm{X}_{1}=$ Current Density $\left(\mathrm{Amp} / \mathrm{dm}^{2}\right)$ & 1.50 & 2.00 & 2.50 & 3.00 & 3.50 \\
\hline $\mathrm{X}_{2}=$ Concentration $($ Vol. $\%)$ & 10.0 & 12.5 & 15.0 & 17.5 & 20.0 \\
\hline $\mathrm{X}_{3}=$ Temperature $\left(\mathrm{C}^{\mathrm{o}}\right)$ & 10.0 & 15.0 & 20.0 & 25.0 & 30.0 \\
\hline $\mathrm{X}_{4}=$ Time $(\mathrm{min})$ & 10.0 & 20.0 & 30.0 & 40.0 & 50.0 \\
\hline
\end{tabular}

Table 3. The analysis of aluminum alloy (3003).

\begin{tabular}{|l|l|l|l|l|l|l|l|l|l|}
\hline Metal & Aluminum & Copper & zinc & Manganese & Silicon & Titanium & Magnesium & Iron & Other's \\
\hline & Rem. & $0.05-0.2$ & 0.1 & $1.0-1.1$ & 0.5 & - & - & 0.7 & 0.05 \\
\hline
\end{tabular}


Table 4.Values of experimental measured thickness for aluminum alloy (3003)

\begin{tabular}{|c|c|c|c|c|c|c|c|c|c|c|c|}
\hline \multirow{2}{*}{$\begin{array}{r}\text { Exp } \\
. \\
\text { No. }\end{array}$} & \multicolumn{4}{|c|}{ Coded variable } & \multicolumn{4}{|c|}{ Real variable } & \multirow{2}{*}{$\begin{array}{l}\text { Exp. } \\
\text { thickness }\end{array}$} & \multirow{2}{*}{$\begin{array}{c}\text { Predicted } \\
\text { thickness } \\
\mathbf{y}(\mu \mathrm{m})\end{array}$} & \multirow{2}{*}{\begin{tabular}{|}
$\begin{array}{r}\text { Corresp. } \\
\text { residual }\end{array}$ \\
e=Y-y
\end{tabular}} \\
\hline & $\mathbf{X} 1$ & $\mathbf{X} 2$ & $\mathrm{X} 3$ & $X 4$ & $\begin{array}{l}\text { Current } \\
\text { Density } \\
\text { A/ } \mathbf{d m}^{2}\end{array}$ & $\begin{array}{r}\text { Conc } \\
\text { Vol } \\
\%\end{array}$ & $\begin{array}{c}\text { Temp } \\
{ }^{\circ} \mathrm{C}\end{array}$ & $\begin{array}{l}\text { Time } \\
(\min )\end{array}$ & & & \\
\hline 1 & -1 & -1 & -1 & -1 & 2.00 & 12.50 & 15.00 & 20.0 & 13.37 & 14.583 & -1.213 \\
\hline 2 & 1 & -1 & -1 & -1 & 3.00 & 12.50 & 15.00 & 20.0 & 18.53 & 17.835 & 0.69504 \\
\hline 3 & -1 & 1 & -1 & -1 & 2.00 & 17.50 & 15.00 & 20.0 & 12.55 & 14.140 & -1.589 \\
\hline 4 & 1 & 1 & -1 & -1 & 3.00 & 17.50 & 15.00 & 20.0 & 20.17 & 21.697 & -1.527 \\
\hline 5 & -1 & -1 & 1 & -1 & 2.00 & 12.50 & 25.00 & 20.0 & 13.19 & 10.675 & 2.5151 \\
\hline 6 & 1 & -1 & 1 & -1 & 3.00 & 12.50 & 25.00 & 20.0 & 16.48 & 16.597 & -0.117 \\
\hline 7 & -1 & 1 & 1 & -1 & 2.00 & 17.50 & 25.00 & 20.0 & 11.02 & 9.967 & 1.05331 \\
\hline 8 & 1 & 1 & 1 & -1 & 3.00 & 17.50 & 25.00 & 20.0 & 20.87 & 20.193 & 0.677 \\
\hline 9 & -1 & -1 & -1 & 1 & 2.00 & 12.50 & 15.00 & 40.0 & 29.90 & 29.930 & -0.0299 \\
\hline 10 & 1 & -1 & -1 & 1 & 3.00 & 12.50 & 15.00 & 40.0 & 36.88 & 37.257 & -0.377 \\
\hline 11 & -1 & 1 & -1 & 1 & 2.00 & 17.50 & 15.00 & 40.0 & 24.45 & 23.675 & 0.775 \\
\hline 12 & 1 & 1 & -1 & 1 & 3.00 & 17.50 & 15.00 & 40.0 & 33.42 & 35.288 & -1.868 \\
\hline 13 & -1 & -1 & 1 & 1 & 2.00 & 12.50 & 25.00 & 40.0 & 27.32 & 25.117 & 2.203 \\
\hline 14 & 1 & -1 & 1 & 1 & 3.00 & 12.50 & 25.00 & 40.0 & 37.35 & 35.113 & 2.237 \\
\hline 15 & -1 & 1 & 1 & 1 & 2.00 & 17.50 & 25.00 & 40.0 & 18.53 & 18.578 & -0.048 \\
\hline 16 & 1 & 1 & 1 & 1 & 3.00 & 17.50 & 25.00 & 40.0 & 34.77 & 32.879 & 1.891 \\
\hline 17 & -2 & 0 & 0 & 0 & 1.50 & 15.00 & 20.00 & 30.0 & 14.13 & 15.310 & -1.18 \\
\hline 18 & 2 & 0 & 0 & 0 & 3.50 & 15.00 & 20.00 & 30.0 & 32.72 & 32.863 & -0.143 \\
\hline 19 & 0 & -2 & 0 & 0 & 2.50 & 10.00 & 20.00 & 30.0 & 23.45 & 25.745 & -2.295 \\
\hline 20 & 0 & 2 & 0 & 0 & 2.50 & 20.00 & 20.00 & 30.0 & 24.04 & 23.068 & 0.972 \\
\hline 21 & 0 & 0 & -2 & 0 & 2.50 & 15.00 & 10.00 & 30.0 & 24.16 & 20.9399 & 3.220 \\
\hline 22 & 0 & 0 & 2 & 0 & 2.50 & 15.00 & 30.00 & 30.0 & 10.08 & 14.623 & -4.543 \\
\hline 23 & 0 & 0 & 0 & -2 & 2.50 & 15.00 & 20.00 & 10.0 & 11.08 & 10.585 & 0.495 \\
\hline 24 & 0 & 0 & 0 & 2 & 2.50 & 15.00 & 20.00 & 50.0 & 36.88 & 38.618 & -1.738 \\
\hline 25 & 0 & 0 & 0 & 0 & 2.50 & 15.00 & 20.00 & 30.0 & 24.09 & 24.048 & 0.042 \\
\hline 26 & 0 & 0 & 0 & 0 & 2.50 & 15.00 & 20.00 & 30.0 & 24.04 & 24.048 & -0.008 \\
\hline 27 & 0 & 0 & 0 & 0 & 2.50 & 15.00 & 20.00 & 30.0 & 24.03 & 24.048 & -0.018 \\
\hline 28 & 0 & 0 & 0 & 0 & 2.50 & 15.00 & 20.00 & 30.0 & 24.03 & 24.048 & -0.018 \\
\hline
\end{tabular}


Tables 5. Analysis of variance of the coefficient effect for aluminum alloy (3003).

\begin{tabular}{|c|c|c|c|c|c|}
\hline $\begin{array}{c}\text { Constant } \\
\text { Estimated }\end{array}$ & $\sum \mathbf{X}^{\mathbf{2}}$ & $\begin{array}{c}\text { Estimated } \\
\text { Coefficient(B) }\end{array}$ & $\begin{array}{c}\text { Variance } \\
\mathbf{S} \mathbf{b}^{\mathbf{2}}=\mathbf{S r}^{\mathbf{2}} / \sum \mathbf{X}^{\mathbf{2}}\end{array}$ & $\begin{array}{c}\mathbf{F} \text {-value } \\
=\mathbf{B}^{\mathbf{2}} / \mathbf{S}_{\mathbf{b}}{ }^{2}\end{array}$ & $\mathbf{F}_{\mathbf{0 . 9 5} \text { (1,13) } \mathbf{4 . 6 7}}$ \\
\hline B1 & 24 & 4.388 & 0.238 & 80.90 & $\mathrm{~S}$ \\
\hline B2 & 24 & -0.669 & 0.238 & 1.88 & $\mathrm{NS}$ \\
\hline B3 & 24 & -1.579 & 0.238 & 10.48 & $\mathrm{~S}$ \\
\hline B4 & 24 & 7.008 & 0.238 & 206.35 & $\mathrm{~S}$ \\
\hline B11 & 48 & 0.0098 & 0.119 & 0.00081 & $\mathrm{NS}$ \\
\hline B22 & 48 & 0.090 & 0.119 & 0.068 & $\mathrm{NS}$ \\
\hline B33 & 48 & -1.567 & 0.119 & 20.63 & $\mathrm{~S}$ \\
\hline B44 & 48 & 0.139 & 0.119 & 0.162 & $\mathrm{NS}$ \\
\hline B12 & 16 & 1.076 & 0.357 & 3.24 & $\mathrm{NS}$ \\
\hline B13 & 16 & 0.668 & 0.357 & 1.25 & $\mathrm{NS}$ \\
\hline B14 & 16 & -0.0575 & 0.357 & 0.009 & $\mathrm{NS}$ \\
\hline B23 & 16 & -0.0663 & 0.357 & 0.012 & $\mathrm{NS}$ \\
\hline B24 & 16 & -1.458 & 0.357 & 5.95 & $\mathrm{~S}$ \\
\hline B34 & 16 & -0.226 & 0.357 & 0.14 & $\mathrm{NS}$ \\
\hline
\end{tabular}

Table 6. Optimum conditions in coded and real values

\begin{tabular}{|l|l|l|l|l|c|}
\hline \multirow{2}{*}{$\begin{array}{l}\text { Opti } \\
\text { conditions }\end{array}$} & \multicolumn{4}{|c|}{ Variables } & $\begin{array}{l}\text { Function Maximum } \\
\text { (Film thick. } \mu \mathrm{m})\end{array}$ \\
\cline { 2 - 5 } & $\begin{array}{l}\text { Current Density } \\
\left(\mathrm{A} / \mathrm{dm}^{2}\right)\end{array}$ & $\begin{array}{l}\text { Electrolyte } \\
\text { Concentration } \\
(\text { Vol\% })\end{array}$ & $\begin{array}{l}\text { Electrolyte } \\
\text { Temperature } \\
\left({ }^{\circ} \mathrm{C}\right)\end{array}$ & $\begin{array}{l}\text { Time of } \\
\text { Anodizing } \\
(\text { min. })\end{array}$ & \multirow{2}{\mathbf{50.4817}}{} \\
\cline { 1 - 5 } Coded & $\mathbf{2}$ & $\mathbf{- 2}$ & $\mathbf{- 0 . 1 8}$ & $\mathbf{2}$ & \\
\cline { 1 - 5 } Real & $\mathbf{3 . 5}$ & $\mathbf{1 0}$ & $\mathbf{1 9}$ & $\mathbf{5 0}$ & \\
\hline
\end{tabular}

Table 7. Roughness values for anodized specimens produced at optimum conditions (Average of 3 reading)

\begin{tabular}{|c|l|}
\hline Al alloy(3003) (before anodiz.) $\mu \mathrm{m}$ & 0.0247 \\
\hline Al alloy(3003) (after anodiz.) $\mu \mathrm{m}$ & 0.38 \\
\hline
\end{tabular}

Table 8. Micro-hardness values for anodized specimens prepared at optimum conditions and bare specimens

\begin{tabular}{|l|c|}
\hline Type of specimens & Micro-hardness value HV \\
\hline Al-alloy(3003) (bare) & 77 \\
\hline Al-alloy (3003) (anodized) & 115 \\
\hline
\end{tabular}


Table 9. Corrosion rates in $3.5 \% \mathrm{NaCl}$ solution

\begin{tabular}{|c|c|c|c|c|c|c|c|c|}
\hline Time (day) & $\mathbf{3}$ & $\mathbf{6}$ & $\mathbf{9}$ & $\mathbf{1 2}$ & $\mathbf{1 5}$ & $\mathbf{2 0}$ & $\mathbf{2 5}$ & $\mathbf{3 0}$ \\
$\begin{array}{c}\text { Corrosion } \\
\text { rates in (mpy) }\end{array}$ & 4.92 & 5.11 & 5.52 & 6.31 & 7.51 & 10.0 & 13.8 & 21.7 \\
\hline Al alloy3003 & 0.35 & 0.44 & 0.62 & 0.95 & 1.1 & 1.85 & 3.0 & 5.2 \\
\hline $\begin{array}{l}\text { Al-alloy3003 } \\
\text { (anodized) }\end{array}$ & & & & & & & & \\
\hline
\end{tabular}

Table 10. Corrosion rates from the polarization curve.

\begin{tabular}{|l|r|}
\hline Type of specimen & Corrosion rate (mpy) \\
\hline Al-alloy (3003) (bare) & 45 \\
\hline Al-alloy (3003) (anodizing) & 36 \\
\hline
\end{tabular}

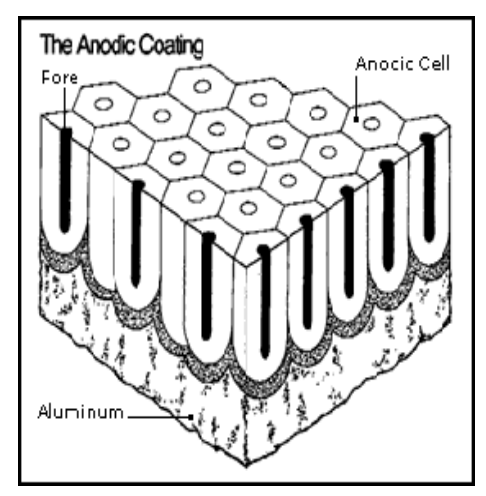

Figure 1. Microstructure of anodic film

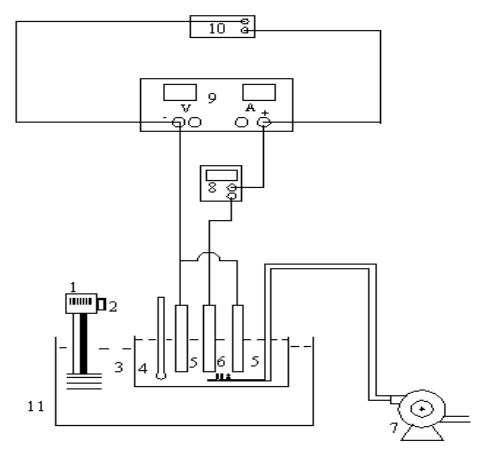

\begin{tabular}{|c|l|}
\hline No. & Item. \\
\hline 1 & Heater - Stirrer \\
\hline 2 & Thermostate. \\
\hline 3 & Anodizing Cell. \\
\hline 4 & Thermometer. \\
\hline 5 & Cathode. \\
\hline 6 & Anode. \\
\hline 7 & Air Pump. \\
\hline 8 & Ammeter. \\
\hline 9 & D.C. power supply. \\
\hline 10 & Voltmeter. \\
\hline 11 & Water bath. \\
\hline
\end{tabular}

Figure 2. Schematic diagram for the whole assembly of the anodizing apparatus 


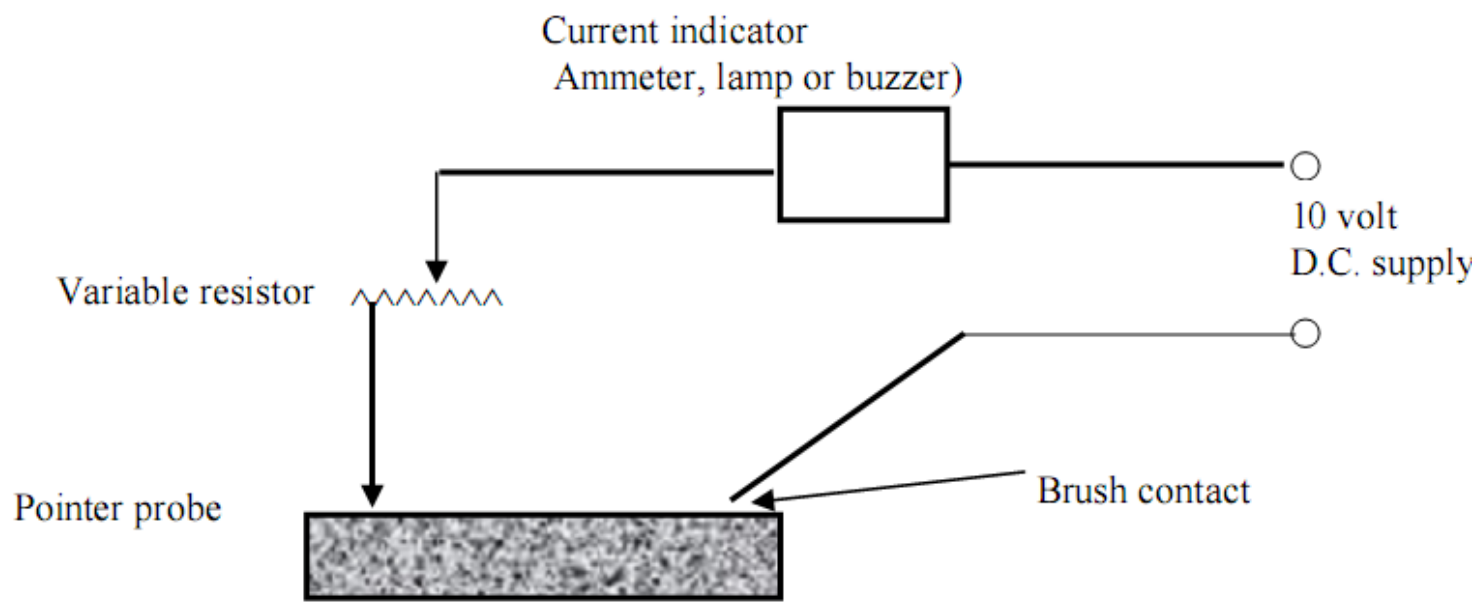

Figure 3. Equipment used in continuity test for anodic coating

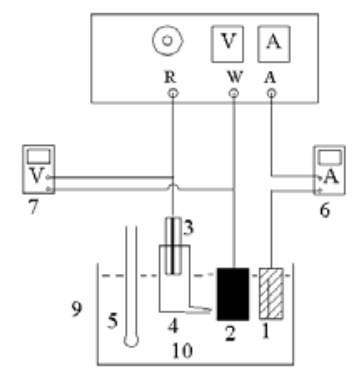

\begin{tabular}{|l|l|}
\hline No. & Item. \\
\hline 1 & Counter electode (Platinum) \\
\hline 2 & Working eletrode \\
\hline 3 & SCE reference electode \\
\hline 4 & Capilling tube \\
\hline 5 & Therometer \\
\hline 6 & Armmeter \\
\hline 7 & Voltmeter \\
\hline 8 & Potentiostate \\
\hline 9 & Corrosion cell \\
\hline 10 & $3.5 \%$ NaCl solution \\
\hline
\end{tabular}

Figure 4. Schematic diagram for potentiostat equipment

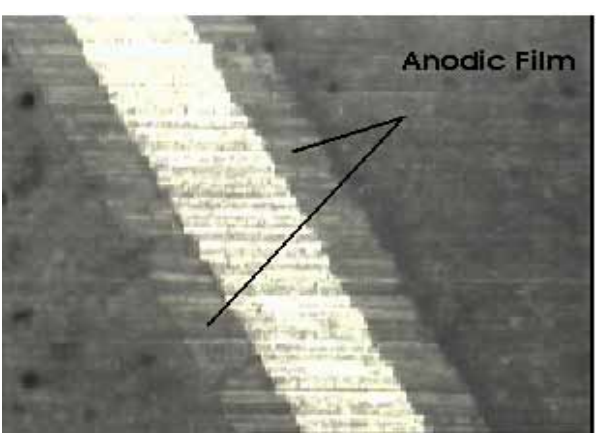

Figure 5. Anodic film thickness aluminum alloy(3003) at optimum conditions 


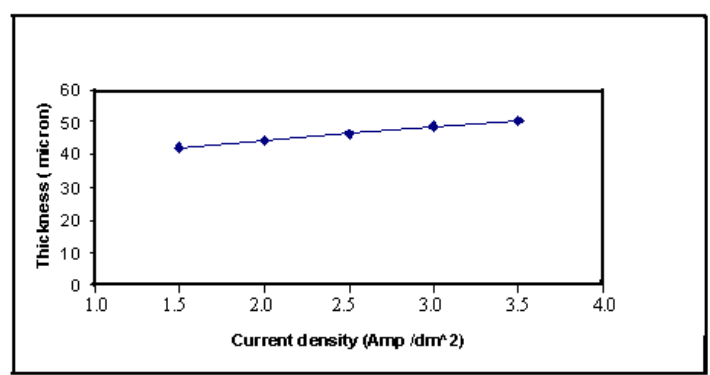

(a)

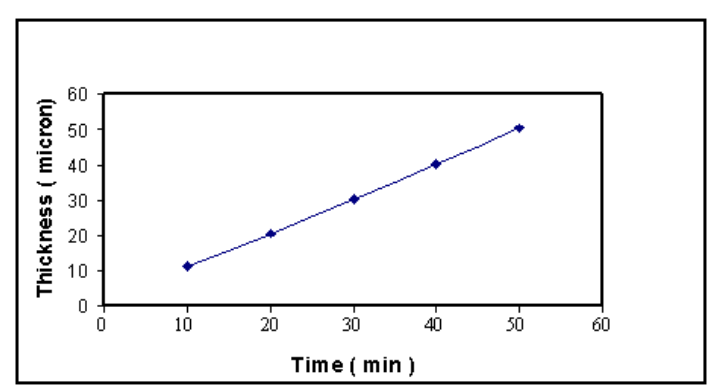

(c)

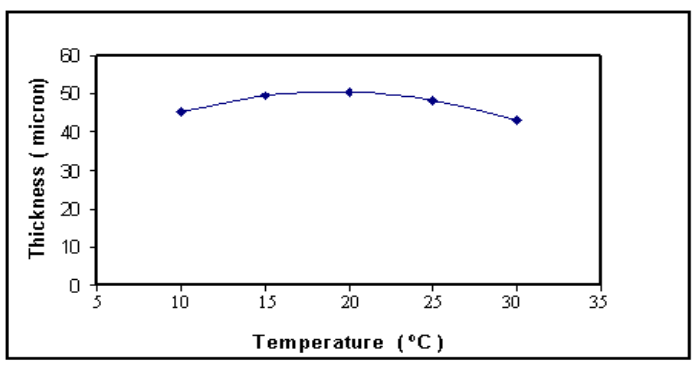

(b)

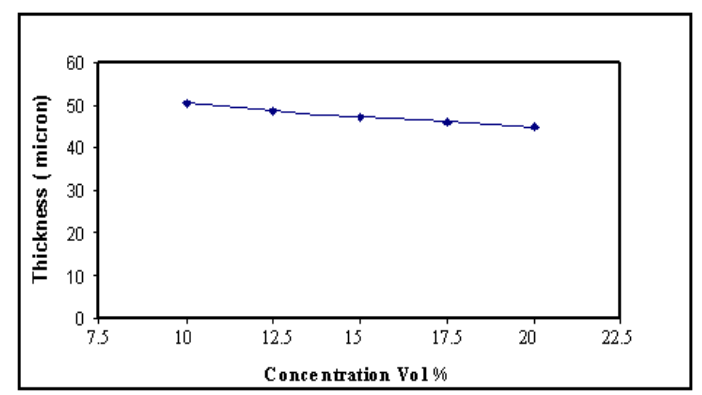

(d)

Figure 6. Effect of the four variables on film thickness at optimum condition (Concentration $=10 \mathrm{Vol} \%$ temperature $=19^{\circ} \mathrm{C}$, and time of anodizing $\left.=50 \mathrm{~min}\right)$ of Al- alloy (3003).
(a) Effect of current density
(b) Effect of temperature
(c) Effect of time
(d) Effect of concentration

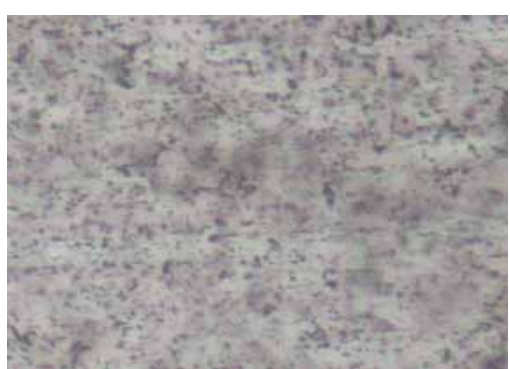

(a)

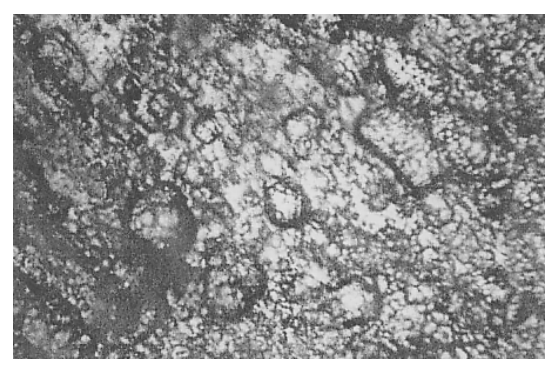

(b)

Figure 7. Surface of Al-alloy (3003)

(a) Before anodizing

(b) After anodizing 


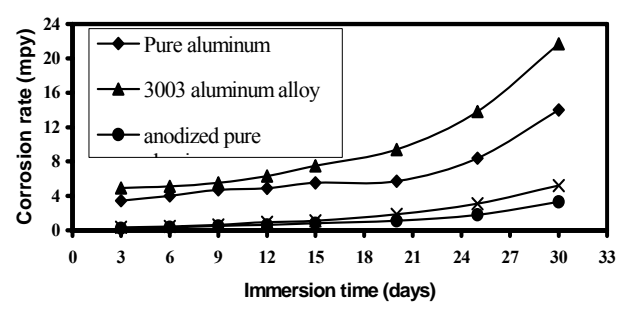

Figure 8. Corrosion rate of aluminum alloy (3003) in $3.5 \% \mathrm{NaCl}$ solution at $25^{\circ} \mathrm{C}$

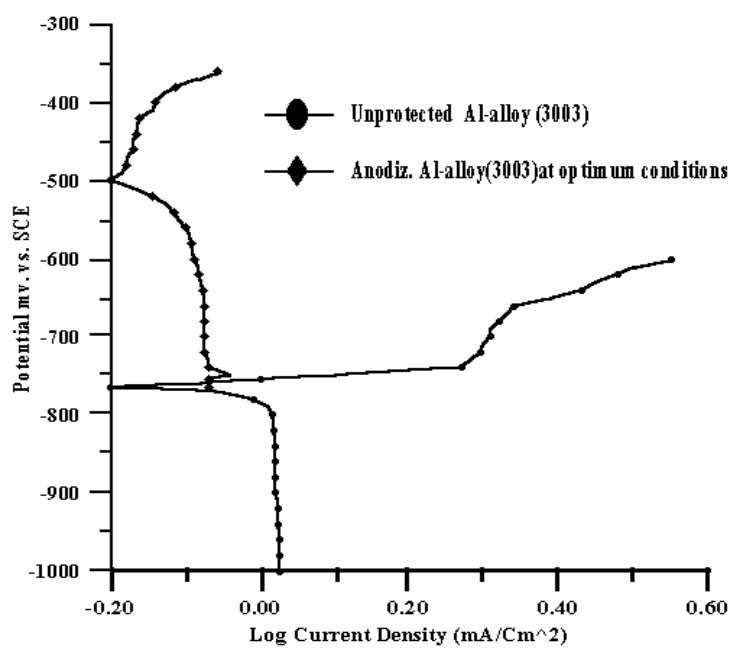

Figure 9. Polarization curve of Al-alloy (3003) in $3.5 \% \mathrm{NaCl}$ solution at $25^{\circ} \mathrm{C}$

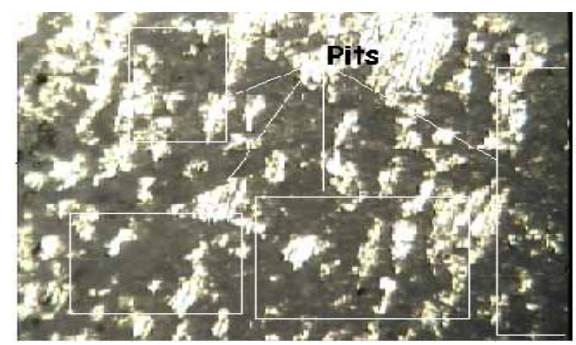

Figure 10. Pitting corrosion on anodized surface of Al-alloy (3003) at (- 400mV SCE) 